\title{
New Disease Reports \\ Mixed infections of pome and stone fruit viroids in cultivated and wild trees in Greece
}

M. Kaponi ${ }^{1} *$, M. Luigi ${ }^{2}$ and P.E. Kyriakopoulou ${ }^{3}$

\begin{abstract}
${ }^{1} 5$ Myrtiotissas, Amaroussion, 15126 Attica, Greece; ${ }^{2}$ Centro di Ricerca per la Patologia Vegetale, Via C.G. Bertero 22, 00156 Rome, Italy; ${ }^{3}$ Professor Emeritus, Agricultural University of Athens, lera Odos 75, 11855 Athens, Greece
\end{abstract}

*E-mail: mkaponi@yahoo.gr

Received: 01 Jun 2012. Published: 15 Sep 2012. Keywords: apple scar skin, hop stunt, pear blister canker

In a survey during 2006-2009, 947 field samples (bark, fruit and leaves) of cultivated and wild pome and stone fruit trees showing various symptoms, including scar skin, dappling, fruit malformation, leaf mottle and stem canker (Fig. 1) were collected in different regions of Greece (Attica, Crete, Macedonia, Peloponnesus and Thessaly). Samples were tested for the presence of Apple scar skin viroid (ASSVd), Hop stunt viroid (HSVd) and Pear blister canker viroid ( $\mathrm{PBCVd})$, using tissue-print molecular hybridisation, reverse transcription-polymerase chain reaction (RT-PCR), cloning and sequencing.

Tissue-print molecular hybridisation showed that approximately 400 trees were infected with only one viroid whereas 63 trees were co-infected by two or three viroids. RT-PCR confirmed mixed infections in 26 trees but the results were not clear for samples from the other trees. Fourteen trees in all, seven pear (Pyrus communis), three wild pear (Pyrus amygdaliformis), three apple (Malus domestica) and one quince (Cydonia oblonga) were infected with ASSVd and PBCVd; five sweet cherry trees (Prunus avium) were infected with ASSVd and HSVd, and seven trees, four apple and three wild apple (Malus sylvestris) were infected with ASSVd, PBCVd and HSVd. All three viroids were sequenced in two trees, ASSVd and PBCVd in a further six trees, and ASSVd and HSVd (partially) in a wild apple tree (Table 1).

Our findings reveal for the first time natural mixed infections of apple and wild apple with ASSVd, PBCVd and HSVd, of quince with ASSVd and PBCVd and of wild apple and sweet cherry with ASSVd and HSVd. Mixed viroid infections of ASSVd, PBCVd and Peach latent mosaic viroid (PLMVd) in pear and wild pear (Kyriakopoulou et al., 2001), of PLMVd and HSVd in peach (Prunus persica) (Hassan et al., 2004, Tessitori et al., 2002) and of PBCVd, PLMVd and HSVd in pear (Fekih-Hassen et al., 2004) have been reported previously. The presence of natural viroid infections in wild species away from human influence in Greece suggests that ASSVd, PBCVd and PLMVd originated in wild hosts and are probably native to Greece (Kyriakopoulou et al., 2001); our data for ASSVd, PBCVd and HSVd support this hypothesis (Kaponi 2009).

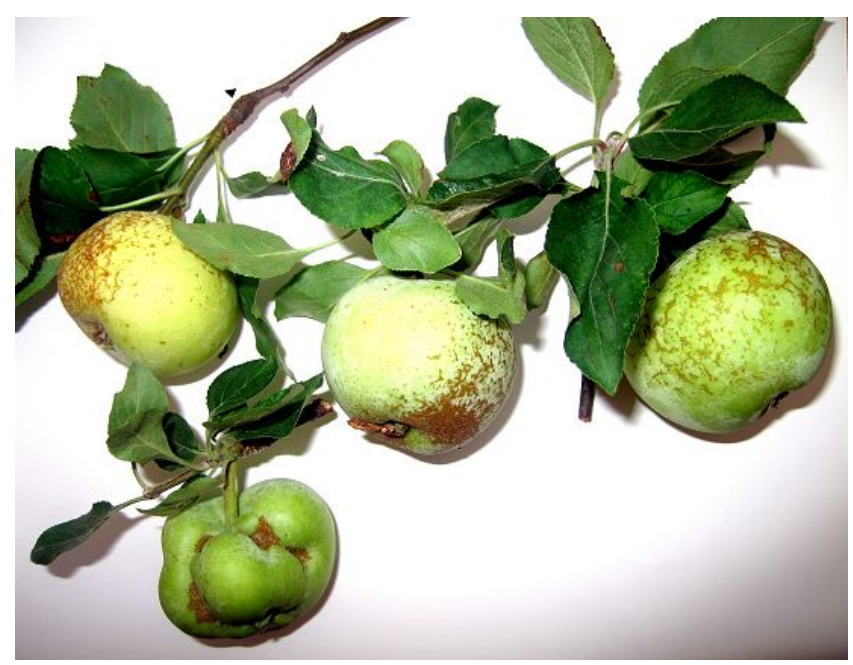

Mixed infections favour viroid recombination and evolution, and wild species used as rootstocks for cultivated species may serve as viroid reservoirs, making phytosanitary control critical (Randles, 2003).

\section{Acknowledgements}

This research project was co-financed by the European Union's European Social Fund (75\%) and the Greek Ministry of Development - GSRT $(25 \%)$. We also thank Dr. Francesco Faggioli, Dr. Marina Barba (CRA, Italy) and Dr Cleanthes Israelides (NAGREF, Greece) for their support

\section{References}

Fekih Hassen I, Kummert J, Marbot S, Fakhfakh H, Marrakchi M, Jijakli MH, 2004. First report of Pear blister canker viroid, Peach latent mosaic viroid, and Hop stunt viroid infecting fruit trees in Tunisia. Plant Disease 88, 1164. [http://dx.doi.org/10.1094/PDIS.2004.88.10.1164A]

Hassan M, Rysanek P, Di Serio F, 2004. Mixed infection of peach trees with Peach latent mosaic viroid and Hop stunt viroid in the Czech Republic. Acta Horticulturae 657, 397-400.

Kaponi MS, 2009. Pome and stone fruit viroids in Greece-molecular characterization and phylogenetic relationships. Athens, Greece: Agricultural University of Athens, PhD thesis.

Kyriakopoulou PE, Giunchedi L, Hadidi A, 2001. Peach latent mosaic and pome fruit viroids in naturally infected cultivated pear Pyrus communis and wild pear $P$. amygdaliformis: implications on possible origin of these viroids in the Mediterranean region. Journal of Plant Pathology 83, 51-62.

Randles JW, 2003. Economic impact of viroid diseases. In: Hadidi A,

Flores R, Randles JW, Semancik JS, eds. Viroids. Collingwood, Australia: CSIRO Publishing, 3-11.

Tessitori M, Reina A, La Rosa R, 2002. First report of mixed infection of Hop stunt viroid and Peach latent mosaic viroid on peach. Plant Disease 86, 329. [http://dx.doi.org/10.1094/PDIS.2002.86.3.329D]

\begin{tabular}{|c|c|c|c|}
\hline $\begin{array}{l}\text { Species and variety, } \\
\text { district - region }\end{array}$ & ASSVId & PBCVd & HSVd \\
\hline $\begin{array}{l}\text { Malus domestica 'Royal Gala', } \\
\text { Pella - Macedonia }\end{array}$ & GQ249349 & FJ974086 & $\begin{array}{l}\text { GQ249348 } \\
\text { EU925589 }\end{array}$ \\
\hline $\begin{array}{l}\text { Malus sylvestris, } \\
\text { Pella - Macedonia }\end{array}$ & FJ974100 & FJ974085 & $\begin{array}{l}\text { FJ974075 } \\
\text { FJ974076 } \\
\text { EU925590 }\end{array}$ \\
\hline $\begin{array}{l}\text { Malus domestica 'Golden Delicious', } \\
\text { Pella - Macedonia }\end{array}$ & $\begin{array}{l}\text { FJ974098 } \\
\text { GQ249347 }\end{array}$ & FJ974088 & \\
\hline $\begin{array}{l}\text { Malus sylvestris, } \\
\text { Pella - Macedonia }\end{array}$ & FJ974099 & GQ141740 & \\
\hline $\begin{array}{l}\text { Malus sylvestris, } \\
\text { Pella - Macedonia }\end{array}$ & FJ974101 & & JX401927 \\
\hline $\begin{array}{l}\text { Malus domestica, } \\
\text { North Athens -Attica }\end{array}$ & FJ974102 & FJ974090 & \\
\hline $\begin{array}{r}\text { Pyrus communis 'Krystalli', } \\
\text { Achaia - Peloponnese }\end{array}$ & FJ974097 & FJ974103 & \\
\hline $\begin{array}{l}\text { Pyrus communis 'Kontoula', } \\
\text { Argolis - Peloponnese }\end{array}$ & $\begin{array}{l}\text { FJ974091 } \\
\text { FJ974092 } \\
\text { FJ974093 }\end{array}$ & FJ974082 & \\
\hline $\begin{array}{l}\text { Pyrus communis 'Kontoula', } \\
\text { Corinthia - Peloponnese }\end{array}$ & FJ974094 & FJ974087 & \\
\hline
\end{tabular}

Figure 2

\section{Figure 1}

To cite this report: Kaponi M, Luigi M, Kyriakopoulou PE, 2012. Mixed infections of pome and stone fruit viroids in cultivated and wild trees in Greece. New Disease Reports 26, 8. [http://dx.doi.org/10.5197/j.2044-0588.2012.026.008]

(c) 2012 The Authors

This report was published on-line at www.ndrs.org.uk where high quality versions of the figures can be found. 